\title{
Carcass Traits and Growth Curve Parameters in Santa Inês Sheep
}

\author{
Natanael Pereira da S. Santos ${ }^{1}$, Cezario B. de Oliveira Neto ${ }^{2}$, Jose Lindenberg R. Sarmento ${ }^{1}$, Leilson R. \\ Bezerra $^{2}$, Ronaldo L. Oliveira ${ }^{3}$, Gleyson V. dos Santos ${ }^{2}$, Aurino de A. Rego Neto ${ }^{1} \&$ Daniel Biagiotti $^{1}$ \\ ${ }^{1}$ Department of Zootechnics, Federal University of Piauí, UFPI, Teresina, Piauí, Brazil \\ ${ }^{2}$ Department of Zootechnics, Federal University of Piauí, UFPI, Bom Jesus, Piauí, Brazil \\ ${ }^{3}$ School of Veterinary Medicine and Zootecnia, UFBA, Salvador, Bahia, Brazil \\ Correspondence: Leilson R. Bezerra, Campus Professora Cinobelina Elvas, Federal University of Piauí, BR 135, \\ km 03, Bairro Planalto Horizonte, Bom Jesus, Piauí State, Brazil. Tel: 89-9984-5518. E-mail: \\ leilson@ufpi.edu.br
}

\author{
Received: February 8, 2014 Accepted: March 18, 2014 Online Published: April 15, 2014 \\ doi:10.5539/jas.v6n5p180 URL: http://dx.doi.org/10.5539/jas.v6n5p180
}

\begin{abstract}
The aim of this study was to evaluate carcass traits and growth curves in Santa Inês sheep. We used weight data collected from 51 developing sheep from birth to 336 days of age, from March 2012 to May 2013. The sheep belonged to the Core Conservation Team of the Federal University of Piaui and were located at two properties, one in Bom Jesus - PI and one in Cristino Castro - PI. The model used to represent the growth curve was the Gompertz model, in which the model parameters were estimated by using a Gauss-Newton algorithm modified by the NLIN procedure in SAS. The rib eye area (REA) and subcutaneous backfat thickness (SBT) of lambs were evaluated by ultrasound. These results were used to study the growth curve and the relationship between the estimated model growth curve parameters and the evaluated carcass traits. The estimated correlation between $\mathrm{A}$ and $\mathrm{K}$ was negative. The correlations between the carcass traits (REA and SBT) and the growth curve parameters (A and K) show that animals with a high adult weight and a high rate of precocity do not always yield good carcasses. Birth weight is a good indicator of animals that can achieve better weights in adulthood. The management effect influenced the growth pattern of Santa Inês sheep, indicating a need to adapt management decisions. These adaptations would mainly relate to fodder storage during periods of food scarcity, which indirectly relates to climate effects, so there would be no influence on animal growth.
\end{abstract}

Keywords: fat, rib eye area, ultrasound, weight

\section{Introduction}

Increasing the effective herd of sheep and consequent availability of food on the consumer's table must be supported by animal breeding programs which are build on an existing knowledge of genetics and the use of biotechnology, which form the basis for production, selection and rapid production of animals with superior genetics (Magalhães, Lobo, \& Facó, 2013).

In this context, we are seeking to understand the relationships among growth and carcass traits, mainly for meat animals, because this understanding can allow avorable changes in early muscling, fat cover and weight gain, which can in turn support decisions regarding the management and selection of breeding animals. With these factors in mind, information in relation to quality housing combined with the pattern of animal growth and improvements in the production system can provide profits to the breeder (Parés-Casanova, 2013).

Ultrasonography is among the most effective assessment methods, and it allows the evaluation of animals without killing them. The use of this technique in animal breeding can be an objective tool for accurately measuring muscularity, fat cover and marbling through growth curves, which help to estimate the efficiency of high commercial value cuts by presenting a positive correlation between the edible portion and the animal's housing (Greiner, Rouse, \& Wilson, 2003). A growth curve study is typically performed by adjusting non-linear functions, which summarize information about the lifespan of the animals in terms of a few biologically interpretable parameters, thereby facilitating the understanding of the growth of the animal. Studies associating nonlinear functions in sheep growth curves with carcass evaluation by in vivo ultrasound are scarce. Thus, the aim of this research was to study the environmental effects and correlations among carcass traits and growth curve parameters as adjusted by the Gompertz model in Santa Ines sheep. 


\section{Materials and Methods}

This research was conducted at the Center for Selection and Conservation of hair sheep at the Federal University of Piauí (management A), in the Corner Farm (management B), in the municipality of Cristino Castro and Lagoa do Barro Farm (management $C$ ) in Bom Jesus, all of which are located in southern Piauí State.

The data were collected in just over one year (March 2012 to May 2013), and 51 animals were used. On management A, 13 collections were performed between March 2012 and January 2013 from 28 animals, which grazed on Andropogon (Andropogon gayanus) during the day and were sampled in the late afternoon, when they received mineral supplementation ad libitum, corn and soybean-based concentrate in covered pens with feeders and collective drinkers. During periods of food scarcity, the animals received feed supplementation using elephant grass (Pennisetum purpureum schum.) and Leucena hay (Leucaena leucocephala lam) in their troughs when necessary. Property B was sampled seven times between June 2012 and January 2013, and measurements were taken for seven animals that were reared exclusively on pasture. These animals grazed on Pangola (Digitaria decumbens) all day, and they were gathered at the end of the day in a covered area. During periods of food scarcity, these animals received feed supplementation based on Elephant Grass (Pennisetum purpureum schum) and cotton cake in their troughs, but they did not receive mineral supplements. Seven collections were performed from 16 animals at management $C$ between May 2012 and January 2013, and the animals remained in irrigated pastures of Tifton (Cynodon spp.) and received mineral supplements at will The required health plan for all the farms was assembled by a professional, and the plan primarily comprised vaccinations, deworming and clinical treatments of caseous lymphadenitis.

The analyzed traits were the body weights at birth, at 56, at 112, at 168, at 224, at 280 and at 336 days of age. The carcass traits were the rib eye area (REA) and subcutaneous backfat thickness (SBT). Carcass measurements were performed using a KX2000G VET ultrasound device, which was equipped with a $3.5 \mathrm{MHz}$ linear transducer for ultrasound readings to be collected after weighing sessions; the animals were kept in the station under comfortable and relaxing conditions for higher quality images. To measure body fat features, images were obtained by positioning the transducer across the dorsal surface between the 12th and 13th thoracic rib, and they were evaluated with a cross section of the longissimus dorsi muscle and analyzed by using measurement tools of their own ultrasound machine. Carcass traits were adjusted based on age, as follows:

$$
A I P_{x}=\left[\frac{\left(\text { caracter } 1-\text { caracter } 1^{\prime}\right)}{\left(\text { age } 1-\text { age } 1^{\prime}\right)}\right] *\left[\left(x-\text { age } 1^{\prime}+\text { caracter } 1^{\prime}\right)\right]
$$

where $A I P_{x}$ is the characteristic age-adjusted standard (REA and SBT were adjusted at a standard age), $\mathrm{x}$ is the age pattern to be adjusted; caracterl is the characteristic measured at the last collection; caracter $1^{\prime}$ is the measured characteristic from a previous collection; agel is the animal's age on the date of the last collection; and agel' is the age of the animal from the previous collection.

The model fit to the growth curve of animals used in this study was the Gompertz model:

$$
Y=A e^{-B e^{-k t}}+\varepsilon
$$

where " $Y$ " is the body weight in $\mathrm{kg}$; "A" is the asymptotic value of " $Y$ "; reached when " $\mathrm{t}$ " tends to infinity and is interpreted as the weight of the adult animal; "B" is the integration constant related to the initial weights and measures; " $\mathrm{m}$ " is the constant that defines the shape of the curve, "e" is the base of the natural logarithm; " $\mathrm{k}$ " is the maturation rate; " $\varepsilon$ " is the random error associated with each weighing; and " $t$ " is the animal's age in days. This last variable is used because a growth curve that fits well after comparing the weight-adjusted ages and the average observed weight is adequate for describing the growth of the animals. The weights were estimated for the same ages with standard carcass characteristics using the Gompertz model for each experimental animal. The model parameters were estimated using the Gauss-Newton algorithm and modified by the NLIN procedure in SAS (1999).

The environment effects used in the analysis were management (A, B and C), sex (male and female), type of birth (single, double and triple), year of collection (2012 and 2013), season of collection (season 01, July-October and season 02, November-June) and animal birth season (season 01, July-October and season 02, November-June).

The statistical model chosen to determine the environmental effects that could influence the shape of the growth curve and carcass traits was as follows: 


$$
Y_{i j k l m n o}=\mu+\operatorname{Pr}_{i}+S_{j}+T n_{k}+A C_{l}+E c_{m}+E n_{n}+\varepsilon_{i j k l m n o}
$$

where $Y_{i j k l m n o}$ is the vector of observations (curve parameters and carcass characteristics); $\mu$ is a constant inherent in the observations; $\operatorname{Pr}_{i}$ is the fixed effect of management $i ; S_{j}$ is the fixed effect of sex $j$; $\operatorname{Tn}_{k}$ is the fixed effect of type of birth $k ; A c_{l}$ is the fixed effect of collection year $l ; E c_{m}$ is the fixed effect of the collection season; $E n_{n}$ is the fixed effect of the birth season; and $\varepsilon_{i j k l m n o}$ is the random error associated with each observation.

Growth curve parameters A, B and K were estimated for each animal, and carcass characteristics were analyzed at standardized ages using the least squares method with the GLM procedure in SAS (1999). The averages estimated by least squares were compared by Tukey's test at $5 \%$ probability. To estimate the sample correlation (Pearson) between the curve parameters, the estimated weights and carcass characteristics, CORR procedure was used the same statistical package, as described above.

\section{Results and Discussion}

The average weights of the animals are within the values observed in the literature for Santa Inês sheep in their respective ages (Table 1). The results indicate that the rate of animal weight gain from birth until 112 days was higher than that during the post-weaning phases. Growth remained stable after 168 days.

Table 1. Descriptive statistics for body birth weights at 336 days of age as estimated by the Gompertz model in Santa Inês sheep in the southern state of Piauí

\begin{tabular}{lccccccc}
\hline \multicolumn{1}{c}{ Weight } & BBW & BW56 & BW 112 & BW168 & BW224 & BW 280 & BW336 \\
\hline Mean (kg) & 3.37 & 11.60 & 17.62 & 21.51 & 24.01 & 25.72 & 26.98 \\
S.D (kg) & 1.37 & 4.18 & 5.04 & 6.24 & 7.49 & 8.44 & 9.15 \\
CV (\%) & 36.41 & 36.01 & 28.62 & 29.02 & 31.21 & 32.83 & 33.93 \\
\hline
\end{tabular}

SD - standard deviation; CV - coefficient of variation; BBW - birth body weight; BW56 - body weight at 56 days; BW112 - body weight at 112 days; BW168 - body weight at 168 days; BW224 - body weight at 224 days; BW280 - body weight at 280 days; BW336 - body weight at 336 days.

Considering that these animals are raised to produce meat, the data indicate that should be slaughtered at approximately 224 days because the animal's weight gain after this age is small, which may cause production losses. Knowing the growth traits of lambs at different stages is of paramount importance for producing sheep meat. To define breeding programs, it is necessary to know the strength of the linear correlation between lamb growth traits (Petrović et al., 2013).

A faster growth phase is observed in young animals, and it is often assumed to be linear (Figure 1). Linear regressions or correlations between weight gain and time are used for the growth models. The coefficients of variation (CV) for the introduced weights had medium to high magnitudes (29.02 to 36.41\%), which can be explained as a consequence of individual variations among animals. The animals were raised in the same region and their variations are embedded in different types of management. 


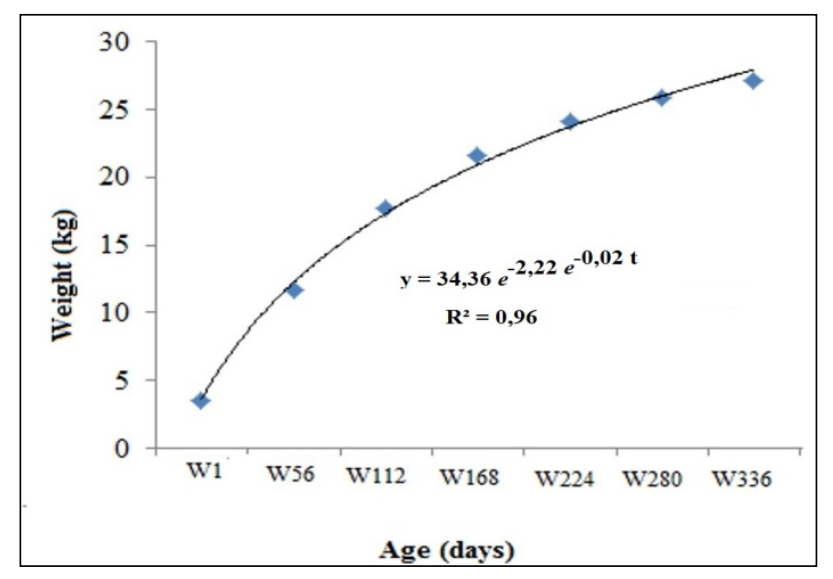

Figure 1. Growth curve of Santa Inês sheep adjusted using the Gompertz model

Effects on the parameters of the Gompertz growth curve were observed (Table 2). The parameters that were interpreted as adult weights were significantly influenced $(\mathrm{P}<0.05)$ by the management effect. Another important parameter is the growth curve $\mathrm{K}$, which can be interpreted as the rate of animal maturation; i.e., it presents the speed at which an animal reaches its asymptotic weight. Thus, the higher the $\mathrm{K}$ value, the greater the precocity of the animal.

Table 2. Effects on the estimated averages of growth curve parameters A, B and K and weights from birth to 336 days for Santa Inês sheep

\begin{tabular}{llllllllllll}
\hline Variables & & A & B & K & BBW & BW56 & BW112 & BW168 & BW224 & BW280 & BW336 \\
\hline \multirow{3}{*}{ Management } & A & $40.31 \mathrm{a}$ & $2.44 \mathrm{a}$ & $0.01 \mathrm{a}$ & $3.78 \mathrm{a}$ & $9.72 \mathrm{~b}$ & $15.67 \mathrm{~b}$ & $20.21 \mathrm{~b}$ & $23.47 \mathrm{~b}$ & $25.89 \mathrm{a}$ & $27.77 \mathrm{a}$ \\
& $\mathrm{B}$ & $15.14 \mathrm{~b}$ & $1.62 \mathrm{~b}$ & $0.02 \mathrm{a}$ & $2.55 \mathrm{~b}$ & $5.46 \mathrm{c}$ & $7.68 \mathrm{c}$ & $9.30 \mathrm{c}$ & $10.52 \mathrm{c}$ & $11.50 \mathrm{~b}$ & $12.30 \mathrm{~b}$ \\
& $\mathrm{C}$ & $32.35 \mathrm{ab}$ & $2.11 \mathrm{ab}$ & $0.03 \mathrm{a}$ & $4.28 \mathrm{a}$ & $17.59 \mathrm{a}$ & $25.39 \mathrm{a}$ & $29.14 \mathrm{a}$ & $30.86 \mathrm{a}$ & $31.65 \mathrm{a}$ & $32.02 \mathrm{a}$ \\
Collection year & 2012 & $39.08 \mathrm{a}$ & $2.39 \mathrm{a}$ & $0.02 \mathrm{a}$ & $4.25 \mathrm{a}$ & $12.36 \mathrm{a}$ & $18.19 \mathrm{a}$ & $21.78 \mathrm{a}$ & $24.28 \mathrm{a}$ & $26.20 \mathrm{a}$ & $27.76 \mathrm{a}$ \\
& 2013 & $27.61 \mathrm{a}$ & $2.10 \mathrm{a}$ & $0.01 \mathrm{a}$ & $3.07 \mathrm{~b}$ & $10.37 \mathrm{a}$ & $16.81 \mathrm{a}$ & $21.12 \mathrm{a}$ & $23.63 \mathrm{a}$ & $25.04 \mathrm{a}$ & $25.85 \mathrm{a}$ \\
Collection & 01 & $34.32 \mathrm{a}$ & $2.25 \mathrm{a}$ & $0.02 \mathrm{a}$ & $3.69 \mathrm{a}$ & $11.59 \mathrm{a}$ & $17.68 \mathrm{a}$ & $21.65 \mathrm{a}$ & $24.21 \mathrm{a}$ & $25.94 \mathrm{a}$ & $27.19 \mathrm{a}$ \\
season & 02 & $34.84 \mathrm{a}$ & $1.87 \mathrm{a}$ & $0.01 \mathrm{a}$ & $4.74 \mathrm{a}$ & $11.81 \mathrm{a}$ & $16.98 \mathrm{a}$ & $19.85 \mathrm{a}$ & $21.70 \mathrm{a}$ & $23.16 \mathrm{a}$ & $24.45 \mathrm{a}$ \\
\multirow{3}{*}{ Birth season } & 01 & $34.89 \mathrm{a}$ & $2.07 \mathrm{~b}$ & $0.01 \mathrm{~b}$ & $3.85 \mathrm{a}$ & $10.71 \mathrm{~b}$ & $16.81 \mathrm{~b}$ & $20.80 \mathrm{a}$ & $23.41 \mathrm{a}$ & $25.23 \mathrm{a}$ & $26.58 \mathrm{a}$ \\
& 02 & $31.84 \mathrm{a}$ & $2.93 \mathrm{a}$ & $0.04 \mathrm{a}$ & $3.38 \mathrm{a}$ & $15.76 \mathrm{a}$ & $21.43 \mathrm{a}$ & $24.81 \mathrm{a}$ & $26.80 \mathrm{a}$ & $28.02 \mathrm{a}$ & $28.85 \mathrm{a}$ \\
Sex & $\mathrm{M}$ & $36.74 \mathrm{a}$ & $2.29 \mathrm{a}$ & $0.02 \mathrm{a}$ & $4.11 \mathrm{a}$ & $12.62 \mathrm{a}$ & $18.61 \mathrm{a}$ & $22.04 \mathrm{a}$ & $24.10 \mathrm{a}$ & $25.51 \mathrm{a}$ & $26.60 \mathrm{a}$ \\
& $\mathrm{F}$ & $32.24 \mathrm{a}$ & $2.16 \mathrm{a}$ & $0.02 \mathrm{a}$ & $3.47 \mathrm{a}$ & $10.70 \mathrm{a}$ & $16.74 \mathrm{a}$ & $21.04 \mathrm{a}$ & $23.93 \mathrm{a}$ & $25.91 \mathrm{a}$ & $27.32 \mathrm{a}$ \\
Type of birth & $\mathrm{D}$ & $31.49 \mathrm{ab}$ & $2.00 \mathrm{~b}$ & $0.02 \mathrm{a}$ & $3.92 \mathrm{a}$ & $12.27 \mathrm{a}$ & $18.29 \mathrm{a}$ & $21.69 \mathrm{a}$ & $23.74 \mathrm{a}$ & $25.15 \mathrm{a}$ & $26.24 \mathrm{a}$ \\
& $\mathrm{D}$ & $45.89 \mathrm{a}$ & $2.82 \mathrm{a}$ & $0.02 \mathrm{a}$ & $3.60 \mathrm{a}$ & $10.76 \mathrm{a}$ & $16.59 \mathrm{a}$ & $21.50 \mathrm{a}$ & $25.16 \mathrm{a}$ & $27.85 \mathrm{a}$ & $29.90 \mathrm{a}$ \\
& $\mathrm{T}$ & $25.34 \mathrm{~b}$ & $1.95 \mathrm{~b}$ & $0.01 \mathrm{a}$ & $3.55 \mathrm{a}$ & $10.85 \mathrm{a}$ & $17.14 \mathrm{a}$ & $20.97 \mathrm{a}$ & $23.06 \mathrm{a}$ & $24.17 \mathrm{a}$ & $24.74 \mathrm{a}$ \\
\hline
\end{tabular}

BBW - birth body weight; BW56 - body weight at 56 days; BW112 - body weight at 112 days; BW168 - body weight at 168 days; BW224 - body weight at 224 days; BW280 - body weight at 280 days; BW336 - body weight at 336 days; parameters of the curve: A - fitted asymptotic weight, B - integration constant and $\mathrm{K}$ - maturation rate; $\mathrm{M}$ - male; F - female; type of birth: S - single, D - double and T - triple; birth season 01 (July-October); birth season 02 (November-June); Means followed by the same letter in the column and effect are not significantly different according to Tukey's test $(\mathrm{P}<0.05)$.

The parameter $\mathrm{K}$ was influenced by the birth season $(\mathrm{P}<0.05)$, indicating that animals born during the rainy season $(0.04)$, when there is more food available, tend to have higher early weights than animals born during the dry season (0.01) because they can gain weight faster from the larger supply of bulk food. In northeastern Brazil, animal production is primarily conducted in naturally grassy areas and is well-known for its importance in the local economy. However, grass productivity and quality characteristics are reduced during the dry season, creating a 
challenge for animal productivity. Furthermore, Furthermore, ruminants for high stocking rate of grazing and shifting cultivation patterns have been identified as the primary factors in the degradation of the Caatinga ecosystem, making this region less available to animals (Pereira Filho, Silva, \& Cézar, 2013).

The management based on which the animals were bred significantly influenced $(\mathrm{P}<0.05)$ all the lamb characteristics, from the parameters of the curve to the weights from birth to 336 days, highlighting the importance of managing the quality of the herd. With respect to parameter a (weight to adulthood), the highest mean weight was found at management $\mathrm{A}(40.31 \mathrm{~kg})$ and the lowest was at management $\mathrm{B}(15.14)$. This finding could be explained by the adoption of mineral and concentrate supplementation at management $\mathrm{A}$, which increased the weight gain of the animals by $72.5 \%$ when compared with management $\mathrm{B}$. The use of diets containing concentrate is used in some cases to accelerate weight gain, improve feed efficiency and consequently reduce the time needed for finishing and yielding greater uniformity in the final product, which adds value and increases producer profits (Cirne et al., 2013). However, the opposite trend was observed for parameter K, which can be explained by the animals with greater precocity not being more likely to achieve a higher weight at maturity than those with slow growth.

Most variables did not affect the animal weights at various ages $(\mathrm{P}>0.05)$. With respect to the birth season and management, animal weights decreased from 56 to 112 days for the season and at all ages for the management, which was expected in response to the availability and use of bulky food concentrate supplements and minerals at certain times of the year $(\mathrm{P}<0.05)$ at management $\mathrm{A}$ and from mineral supplementation all year in management $\mathrm{C}$. Integration constant $\mathrm{B}$ has no biological interpretation; however, it is important to model the growth curve from birth to adulthood, which is barely influenced by the birth season effect.

With respect to housing characteristics, the management was the variable that most influenced carcass characteristics because of differences in animal handling (Table 3). The animals at management $\mathrm{C}$ presented larger REA and SBT values $\left(6.82\right.$ and $\left.1.24 \mathrm{~cm}^{2}\right)$ than those at management $\mathrm{A}\left(3.83\right.$ and $\left.0.96 \mathrm{~cm}^{2}\right)$ and management $\mathrm{B}$ $\left(1.58\right.$ and $\left.0.54 \mathrm{~cm}^{2}\right)(\mathrm{P}<0.05)$. This behavior occurred during all studied periods $(56,112$ and 224 days $)$. This finding can most likely be explained by the genetic quality of animals raised on this management because as we can see in Table 2, animals of various ages at management $\mathrm{C}$ had higher weights $(\mathrm{P}<0.05)$ than those at properties $\mathrm{B}$ and $\mathrm{A}$. At 224 days, management $\mathrm{C}$ had an REA that was $82 \%$ higher than that of management $\mathrm{B}$ and $50 \%$ higher than that of management A.

Table 3. Effects on the estimated averages of carcass characteristics, rib eye area and subcutaneous backfat thickness, for ages 56,112 and 224 days for Santa Inês sheep

\begin{tabular}{|c|c|c|c|c|c|c|c|}
\hline \multirow{2}{*}{ Variables } & & \multicolumn{3}{|c|}{ REA } & \multicolumn{3}{|c|}{ SBT } \\
\hline & & BW56 & BW112 & BW224 & BW56 & BBW112 & BW224 \\
\hline \multirow{3}{*}{ Management } & A & $2,88 \mathrm{~b}$ & $3,53 b$ & $5,08 \mathrm{~b}$ & $0,82 b$ & $0,87 \mathrm{~b}$ & $1,20 \mathrm{a}$ \\
\hline & B & $1,39 \mathrm{c}$ & $1,60 \mathrm{c}$ & $1,77 \mathrm{c}$ & $0,74 \mathrm{~b}$ & $0,50 \mathrm{c}$ & $0,38 b$ \\
\hline & $\mathrm{C}$ & $4,13 \mathrm{a}$ & $6,49 a$ & $9,84 \mathrm{a}$ & $1,11 \mathrm{a}$ & $1,27 \mathrm{a}$ & $1,35 \mathrm{a}$ \\
\hline \multirow{2}{*}{ Collection year } & 2012 & $3,21 \mathrm{a}$ & $4,35 \mathrm{a}$ & $7,27 \mathrm{a}$ & $0,95 \mathrm{a}$ & $0,96 \mathrm{a}$ & $1,31 \mathrm{a}$ \\
\hline & 2013 & $2,86 \mathrm{a}$ & $3,97 \mathrm{a}$ & $4,71 \mathrm{~b}$ & $0,83 a$ & $0,91 \mathrm{a}$ & $0,86 \mathrm{~b}$ \\
\hline \multirow{2}{*}{ Collection season } & 1 & $3,08 \mathrm{a}$ & $4,25 \mathrm{a}$ & $6,11 \mathrm{a}$ & $0,89 \mathrm{a}$ & $0,96 \mathrm{a}$ & $1,08 \mathrm{~b}$ \\
\hline & 2 & $2,86 \mathrm{a}$ & $3,53 \mathrm{a}$ & $7,54 \mathrm{a}$ & $0,98 \mathrm{a}$ & $0,79 \mathrm{a}$ & $1,89 \mathrm{a}$ \\
\hline \multirow{2}{*}{ Birth season } & 1 & $2,92^{\mathrm{a}}$ & $3,71 \mathrm{~b}$ & $5,78 \mathrm{~b}$ & $0,84 \mathrm{~b}$ & $0,91 \mathrm{a}$ & $1,21 \mathrm{a}$ \\
\hline & 2 & $3,77 \mathrm{a}$ & $6,45 \mathrm{a}$ & $8,20 \mathrm{a}$ & $1,20 \mathrm{a}$ & $1,11 \mathrm{a}$ & $0,93 \mathrm{a}$ \\
\hline \multirow{3}{*}{ Sex } & M & $3,21 \mathrm{a}$ & $4,50 \mathrm{a}$ & $7,11 \mathrm{a}$ & $0,96 \mathrm{a}$ & $0,93 \mathrm{a}$ & $1,32 \mathrm{a}$ \\
\hline & $\mathrm{F}$ & $2,85 \mathrm{a}$ & $3,92 \mathrm{a}$ & $5,44 \mathrm{a}$ & $0,84 \mathrm{a}$ & $0,96 \mathrm{a}$ & $0,98 \mathrm{a}$ \\
\hline & $\mathrm{S}$ & $3,33 \mathrm{a}$ & $4,26 \mathrm{a}$ & $6,38 \mathrm{a}$ & $0,95 \mathrm{a}$ & $0,90 \mathrm{a}$ & $1,14 \mathrm{a}$ \\
\hline \multirow[t]{2}{*}{ Type of birth } & D & $2,59 a$ & $3,87 \mathrm{a}$ & $6,57 \mathrm{a}$ & $0,87 \mathrm{a}$ & $0,88 \mathrm{a}$ & $1,19 \mathrm{a}$ \\
\hline & $\mathrm{T}$ & $2,98 \mathrm{a}$ & $4,49 \mathrm{a}$ & $5,25 \mathrm{a}$ & $0,79 a$ & $1,17 \mathrm{a}$ & $1,14 \mathrm{a}$ \\
\hline
\end{tabular}

REA - rib eye area; SBT - subcutaneous backfat thickness; M - male; F - female; type of birth: S - single, D double and T - triple; birth season 01 (July-October); birth season 02 (November-June); BBW - birth body weight; BW56 - body weight at 56 days; BW112 - body weight at 112 days; BW224 - body weight at 224 days; Means followed by the same letter in the column and effect are not significantly different according to Tukey's test $(\mathrm{P}<0.05)$. 
The collection year only influenced the REA and SBT values of animals at 224 days $(\mathrm{P}<0.05)$, with the data from 2012 having higher values than those from 2013. This finding most likely reflects the cumulative effect of a drought that has been plaguing the region. In accordance with this condition, the collection station influenced the SBT until 224 days, and season 02 had higher values $(\mathrm{P}<0.05)$ for the rainy season and provided more pasture availability for animals.

The sex of the animal did not affect $(\mathrm{P}>0.05)$ carcass characteristics, contrary to expectation, because sexual dimorphism may influence tissue growth. Nevertheless, the literature reports that there are no significant sex effects on carcass characteristics, with the exception of taste. Females have more desirable meat than males, especially when heavier carcasses are evaluated for the influence of hormonal factors (Navajas et al., 2008; Arsenos et al., 2002).

Despite not having resulted in a significant difference $(\mathrm{P}>0.05)$, the type of birth must be entered into the analysis model to control for variations because animals with triple births showed better values than animals with double and single births; this effect may occur as a result of the small number of animals coming from triple births and having normal deliveries when compared with single and double births. It is noteworthy that single births tended to have better carcass characteristic values because of the lack of competition for food (Abdel-Aziz, Nishida, Suzuki, $\&$ Nishida, 2005; Sarmento et al., 2011).

The sample correlation between weight and the asymptotic rate of maturation in the adjusted model was of low and negative (-0.26) (Table 4).

Table 4. Pearson correlation coefficients of carcass characteristics and parameters of growth curve of Santa Inês sheep

\begin{tabular}{lllllllll}
\hline & B & K & REA 56 & REA 112 & REA 224 & SBT 56 & SBT 112 & SBT 224 \\
\hline A & $0,30^{*}$ & $-0,26^{*}$ & $0,10^{*}$ & $-0,06^{*}$ & $0,04^{*}$ & $-0,21$ & $-0,13^{*}$ & $0,03^{*}$ \\
B & - & $-0,15^{*}$ & $-0,11^{*}$ & $-0,05$ & $0,03^{*}$ & $-0,02$ & 0,05 & $-0,00$ \\
K & & - & $0,06^{*}$ & $0,28^{*}$ & 0,31 & $0,23^{*}$ & $-0,08^{*}$ & $-0,14^{*}$ \\
REA 56 & & & - & $0,69^{*}$ & $0,56^{*}$ & $0,48^{*}$ & $0,40^{*}$ & $0,37^{*}$ \\
REA 112 & & & - & $0,74^{*}$ & $0,48^{*}$ & $0,62^{*}$ & $0,26^{*}$ \\
REA 224 & & & & - & $0,43^{*}$ & $0,57^{*}$ & $0,48^{*}$ \\
SFT 56 & & & & & - & $0,26^{*}$ & $0,38^{*}$ \\
SFT 112 & & & & & - & - & $0,31^{*}$
\end{tabular}

*significant at 5\% using Pearson coefficient parameters of the curve: A - fitted asymptotic weight, B - integration constant and $\mathrm{K}$ - maturation rate; REA 56: rib eye area achieved at 56 days of age; REA 112: rib eye area achieved at 112 days of age; REA 224: rib eye area achieved at 224 days of age; SBT 56: subcutaneous backfat thickness achieved at 224 days of age; SBT 112: subcutaneous backfat thickness achieved at 112 days of age; and SBT 224: subcutaneous backfat thickness achieved at 224 days of age.

This trend becomes evident when observing that parameters A and $\mathrm{k}$ have a negative correlation, which can be explained by the tendency of the heavier animals to have lower maturation rates than lighter animals, and they would reach maturation at younger ages; similar results have been reported by Sarmento et al. (2006).

It is noteworthy that the loin eye area and fat thickness showed low correlations and even a negative correlation with respect to parameters $\mathrm{A}$ and $\mathrm{K}(0.28$ and -0.21$)$, respectively. This finding may indicate that animals with early maturation and high weights in adulthood do not always present satisfactory REA sizes and good SBT coverage. However, by having a high commercial value in relation to prime cuts of sheep, the REA carcass characteristics should be observed when assessing the performance of the animal and not just the weight. Similarly, the correlation of the SBT with the parameter estimate was low (0.21).

For carcass traits, there were positive correlations ranging from low (0.26) to high (0.74), indicating that the REA and SBT were directly connected; that is, animals with good-sized REAs tended to have good SBTs. These two characteristics are highly valued. 
The correlation between the parameter and the adjusted weights for different ages (Table 5) was positive for low and medium magnitudes. There was a higher correlation between A and BBW, indicating that animals with good birth weights have greater weights in adulthood than animals of the same birth season and lower weights.

Table 5. Pearson correlation coefficients adjusted for body weights from birth to 336 days and the parameters of the growth curve of Santa Inês sheep

\begin{tabular}{llllllllll}
\hline & B & K & BBW & BW56 & BW112 & BW168 & BW224 & BW280 & BW336 \\
\hline A & $0,30^{*}$ & $-0,26^{*}$ & $0,54^{*}$ & 0,05 & 0,10 & $0,21^{*}$ & $0,32^{*}$ & $0,42^{*}$ & $0,51^{*}$ \\
B & - & $-0,15^{*}$ & $-0,30$ & $-0,22^{*}$ & $-0,05^{*}$ & 0,13 & 0,24 & $0,30^{*}$ & 0,33 \\
K & & - & $-0,14$ & $0,27^{*}$ & $0,07^{*}$ & $-0,05^{*}$ & $-0,14$ & $-0,20^{*}$ & $-0,24^{*}$ \\
BBW & & & - & $0,50^{*}$ & $0,41^{*}$ & $0,35^{*}$ & $0,33^{*}$ & $0,34^{*}$ & $0,36^{*}$ \\
BW56 & & & - & $0,91^{*}$ & $0,76^{*}$ & $0,62^{*}$ & $0,51^{*}$ & $0,43^{*}$ \\
BW 112 & & & & - & $0,94^{*}$ & $0,85^{*}$ & $0,75^{*}$ & $0,67^{*}$ \\
BW 168 & & & & & - & $0,97^{*}$ & $0,91^{*}$ & $0,84^{*}$ \\
BW 224 & & & & & & - & $0,98^{*}$ & $0,94^{*}$ \\
BW 280 & & & & & & & - & $0,98^{*}$
\end{tabular}

*significant at $5 \%$ using Pearson coefficient parameters of the curve: A - fitted asymptotic weight, B - integration constant and $\mathrm{K}$ - maturation rate; BBW - birth body weight; BW56 - body weight at 56 days; BW112 - body weight at 112 days; BW168 - body weight at 168 days; BW224 - body weight at 224 days; BW280 - body weight at 280 days; BW336 - body weight at 336 days.

With respect to parameter K, the correlation between weights decreased gradually until 112 days later, when there was a gradual decrease in the correlation, with changes in the direction of the degree of association between variables.

Similar results were observed by Sarmento et al. (2006), thereby confirming the negative correlation between these parameters. Moderate to high correlations were found between the weights at different ages; an animal that has a good birth weight tends to maintain its gain at subsequent ages. These weights were close, evidence the influence that subsequent to the weights. Note that animals with high adult weights and high rates of precocity did not always have good carcass yields and that birth weight is a good indicator of animals that can achieve better weights in adulthood.

\section{Conclusions}

Carcass traits should be included in the evaluation to allow for better gains in meat quality. The Gompertz model can be utilized for adjustment the growth curve parameters in Santa Inês sheep. Parameters A and K indicate that the animals have a smaller chance of gaining weight in their development to achieve high weights in adulthood

\section{References}

Abdel-Aziz, M., Nishida, S., Suzuki, K., \& Nishida, A. (2005). Estimation of direct and maternal genetic parameters for growth and carcass traits in a herd of Japanese Black cattle in Miyagi prefecture, using a multitrait animal model. Journal of Animal Science, 76, 187-193. http://dx.doi.org/10.1111/j.1740-0929.2005.00255.x

Arsenos, G., Banos, G., Fortomaris, P., Katsaounis, N., Stamataris, C., \& Tsaras, L. (2002). Eating quality of lamb meat: Effect of breed, sex, degree of maturity and nutritional management. Meat Science, 60, 379-387. http://dx.doi.org/10.1016/S0309-1740(01)00147-4

Cirne, L. G. A., Oliveira, G. J. C., Jaeger, S. M. P. L., Bagaldo, A. R., Leite, M. C. P., Oliveira, P. A., \& Macedo Junior, C. M. (2013). Performance of feedlot lambs feed with exclusive concentrate diet with different percentages of protein. Arquivo Brasileiro de Medicina Veterinária e Zootecnia, 65, 262-266. http://dx.doi.org/10.1590/S0102-09352013000100037

Greiner, S. P., Rouse, G. H., \& Wilson, D. E. (2003). The relationships between ultrasound measurements and carcass fat thickness and longissimus muscle area in beef cattle. Journal of Animal Science, 81, 676-682. 
Magalhães, A. F. B., Lobo, R. N. B., \& Facó, O. (2013). Genetic parameters estimates for growth traits in Somalis Brasileira hair sheep breed. Ciência Rural, 43, 884-889. http://dx.doi.org/10.1590/S0103-84782013005000043

Navajas, E. A., Lambe, N. R., Fisher, A. V., Nute, G.,R., Bünger, L., \& Simm, G. (2008). Muscularity and eating quality of lambs: Effects of breed, sex and selection of sires using muscularity measurements by computed tomography. Meat Science, 79, 105-112. http://dx.doi.org/10.1016/j.meatsci.2007.08.006

Parés-Casanova, P. M. (2013). Morphometric dimensions allow differentiation of lamb carcasses for some breeds. Egyptian Journal of Sheep and Goat Sciences, 8, 167-170.

Pereira Filho, J. M., Silva, A. M. A., \& Cézar, M. F. (2013). Manejo da Caatinga para produção de caprinos e ovinos. Revista Brasileira de Saúde e Produção Animal, 14, 77-90.

Petrović, V. C., Petrović, M. P., Petrovic, M. M., Ilić, Z., Stojković, J., Ružić Muslić, D., \& Maksimovic, N. (2013). The linear relationship between growth traits of sharplanina lambs in extensive farming practices. Biotechnology in Animal Husbandry, 29, 287-297. http://dx.doi.org/10.2298/BAH1302287C

Sarmento, J. L. R., Regazzi, A. J., Sousa, W. H., Torres, R. A., Breda, F. C., \& Menezes, G. R. O. (2006). Estudo da curva de crescimento de ovinos Santa Inês. Revista Brasileira de Zootecnia, 35, 435-442.

Sarmento, J. L. R., Torres, R. A., Sousa, W. H., Lôbo, R. N. B., Sousa, J. E. R., Cavalcante Neto, A., \& Do Ó, A. O. (2011). Efeito materno sobre a curva de crescimento de ovinos Santa Inês por meio de modelos de regressão aleatória. Comunicata Scientiae, 2, 113-121. http://dx.doi.org/10.1590/S1516-35982006000200014

SAS. (1999). Statistical analyses system user's guide (Version 8). Cary, NC: SAS Institute Inc., Raleigh, North Carolina, USA.

\section{Copyrights}

Copyright for this article is retained by the author(s), with first publication rights granted to the journal.

This is an open-access article distributed under the terms and conditions of the Creative Commons Attribution license (http://creativecommons.org/licenses/by/3.0/). 